\title{
PERILAKU PEMELIHARAAN KESEHATAN GIGI DAN MULUT SERTA KONDISI JARINGAN PERIODONTAL PADA SISWA SMA NEGERI 1 SALEM
}

\author{
Hadiyat Miko ${ }^{1}$ Muhammad Saleh $^{2}$ \\ ${ }^{1}$ Dental Therapy, Poltekkes Kemenkes Tasikmalaya, Jawa Barat, Indonesia \\ ${ }^{2}$ Dental Hygiene, Poltekkes Kemenkes Makassar, Sulawesi Selatan, Indonesia \\ *drgmiko@yahoo.com
}

\section{Kata kunci:}

Mengunyah mentimun, kebersihan gigi dan mulut

\section{ABSTRAK}

Tujuan dari penelitian ini adalah untuk mengetahui gambaran perilaku pemeliharaan kesehatan gigi dan mulut dengan kondisi jaringan periodontal pada Siswa SMA Negeri 1 Salem Kecamatan Salem Kabupaten Brebes. Jenis penelitian ini adalah penelitian observasional dengan metode deskriptif. Populasi pada penelitian ini adalah Siswa Kelas XI IPS 1 SMA Negeri 1 Salem Kecamatan Salem Kabupaten Brebes yang berjumlah 36 orang, semua populasi dijadikan sampel dalam penelitian. Data primer yang diambil yaitu penyakit jaringan periodontal dan kebutuhan perawatan pada Siswa Kelas XI IPS 1 dengan pemeriksaan Community Periodontal Index of Treatment Needs (CPITN), pengolahan dan analisis data menggunakan distribusi frekuensi. Berdasarkan hasil penelitian dapat disimpulkan sebagai berikut: 1) Rata-rata kondisi jaringan periodontal siswa kelas XI IPS 1 SMAN 1 Salem berdasarkan hasil pemeriksaan Community Periodontal Index of Treatment Needs (CPITN) yaitu adanya subgingival calculus; 2) Rata-rata siswa kelas XI IPS 1 SMAN 1 Salem memiliki perilaku pemeliharaan kesehatan gigi dan mulut dengan kriteria sedang.

Key word:

Chewing cucumbers, dental and oral hygiene

\section{ABSTRACT}

The purpose of this study was to determine the picture of dental and oral health maintenance behavior with periodontal tissue conditions in SMA Negeri 1 Salem Kecamatan Salem Kabupaten Brebes. This type of research is observational research with descriptive methods. The population in this study were students of Class XI IPS 1 SMA Negeri 1 Salem Kecamatan Salem Kabupaten Brebes with a total of 36 people, all populations were sampled in the study. Primary data taken are periodontal tissue disease and treatment needs in Class XI IPS 1 students with Community Periodontal Index of Treatment Needs (CPITN) examination, data processing and analysis using frequency distribution. Based on the results of the study it can be concluded as follows: 1) The average periodontal tissue condition of the XI IPS 1 SMAN 1 Salem based on the results of the Community Periodontal Index of Treatment Needs (CPITN) examination, namely the existence of subgingival calculus; 2) The average XI IPS 1 SMAN 1 Salem has moderate health and dental maintenance behaviors. 


\section{PENDAHULUAN}

Kesehatan adalah keadaan sehat, baik secara fisik, mental, spiritual maupun sosial yang memungkinkan setiap orang untuk hidup produktif secara sosial dan ekonomis. Derajat kesehatan masyarakat perlu dipelihara dan ditingkatkan yaitu melalui pelayanan kesehatan gigi dan mulut (Kemenkes, 2010).

Kesehatan mulut penting bagi kesehatan dan kesejahteraan tubuh secara umum dan sangat mempengaruhi kualitas kehidupan, sehingga apabila seseorang mempunyai penyakit gigi dan mulut atau gangguan kesehatan mulut akan berdampak pada kinerja orang tersebut (Putri, dkk., 2010). Kesehatan gigi dan mulut merupakan salah satu aspek dari kesehatan secara keseluruhan, dengan demikian maka status kesehatan gigi dan mulut juga merupakan hasil dari interelasi antara kondisi fisik, mental dan sosial (Herijulianti, dkk., 2001)

Penyakit gigi dan mulut terutama karies dan penyakit periodontal masih banyak diderita, baik oleh anak-anak, remaja maupun usia dewasa. Berdasarkan hasil Survey Kesehatan Rumah Tangga (SKRT) Tahun 2004, prevalensi penyakit periodontal di Indonesia menunjukkan hasil 60\%. Dalam Ilmu Kedokteran Gigi, jaringan pendukung gigi dikenal dengan istilah periodontium. Kata periodontium berasal dari bahasa Yunani, yaitu peri: disekeliling, odont: gigi. Jadi periodontium artinya disekeliling gigi (Nio, 1987). Penyakit yang merusak periodontal atau periodontitis biasanya menunjuk pada kondisi inflamasi yang meningkat menjadi pembentukan poket, hilangnya perlekatan dan akhirnya hilangnya tulang penyangga gigi (Burt dkk., 1982; Harris, 2004, cit. Sriyono, 2005)

Faktor penyebab dari penyakit periodontal salah satunya adalah plak yang disebabkan oleh rendahnya perilaku dalam memelihara kebersihan gigi dan mulut. Hal ini dapat dilihat dari $6,2 \%$ penduduk indonesia tidak menyikat gigi dan dari 93,8\% yang menyikat gigi hanya 2,3\% yang menyikat gigi tepat waktu (Riskesdas, 2013). Perilaku adalah semua kegiatan atau aktivitas manusia, baik yang dapat diamati langsung maupun yang tidak dapat diamati oleh pihak luar (Notoatmodjo, 2012). Benyamin Bloom (1908), seorang ahli psikologi pendidikan membagi perilaku manusia itu ke dalam tiga domain sesuai dengan tujuan pendidikan. Bloom menyebutnya ranah atau kawasan yakni: kognitif, afektif dan psikomotor.

Rendahnya perilaku masyarakat dalam memelihara kebersihan gigi dan mulut disebabkan oleh kurangnya kesadaran akan perilaku hidup sehat. Menurut Green (1991), perilaku adalah kegiatan manusia atau makhluk hidup yang dapat dilihat secara langsung pada waktu tertentu di suatu tempat tertentu dan menurut Becker (1979), perilaku hidup sehat merupakan upaya atau kegiatan seseorang untuk mempertahankan dan meningkatkan kesehatannya. Konsep Blum (1974), seperti yang dikutip oleh Azwar (1983), menegaskan bahwa perilaku merupakan salah satu faktor yang bisa mempengaruhi sehat atau tidaknya seseorang selain faktor lingkungan, faktor keturunan dan faktor pelayanan kesehatan (Fitriani, 2011), sehingga perilaku tentang pemeliharaan kesehatan gigi dan mulut sangat penting bagi seseorang untuk memelihara dan menjaga kesehatan gigi dan mulutnya agar terhindar dari masalah kesehatan gigi dan mulut, seperti halnya penyakit pada jaringan penyangga gigi (jaringan periodontal). Konsep Blum tahun 1974, seperti dikutip oleh Azwar (1983), menegaskan bahwa tidak hanya perilaku yang mempengaruhi sehat atau tidaknya seseorang tetapi ada faktor-faktor lain, yaitu faktor lingkungan, faktor keturunan dan faktor pelayanan kesehatan (Fitriani, 2011).

Jaringan periodontal (jaringan penyangga gigi) merupakan jaringan penyokong yang menyangga gigi agar tetap tertanam pada tulang elveolar dengan demikian dapat mendukung gigi, sehingga gigi tidak terlepas dari soketnya. Keadaan jaringan periodontal pada setiap individu sangat bervariasi, bergantung atau dipengaruhi oleh morfologi gigi, fungsi, maupun usia. Indeks pengukuran kondisi jaringan periodontal meliputi Periodontal 
Index (PI), Periodontal Disease Index (PDI), Gingival Index (GI), Gingival Bleeding Index (GBI) dan Community Periodontal Index of Treatment Needs (CPITN). Community Periodontal Index of Treatment Needs (CPITN) merupakan indeks resmi yang digunakan oleh WHO untuk mengukur kondisi jaringan periodontal serta perkiraan kebutuhan perawatannya (Putri, dkk., 2010).

Prevalensi penyakit periodontal masih tetap tinggi dan tidak hanya menyerang populasi usia dewasa saja melainkan juga usia remaja. Hal ini dapat dilihat dari penelitian keadaan jaringan periodontal pada pelajar di Iran ialah 14,5\% memiliki jaringan periodontal yang sehat, 33,7\% mengalami perdarahan gingiva, dan ditemukan kalkulus pada 48,7\% sampel (WHO, 2005, cit. Suling, dkk., 2013). Oleh karena itu, pemeriksaan dan promosi kesehatan gigi dan mulut, terutama pemeriksaan kondisi jaringan periodontal penting untuk dilakukan.

WHO menetapkan sekolah dan remaja dijadikan sebagai kelompok target yang penting untuk dilakukan pemeriksaan dan promosi kesehatan gigi dan mulut diantaranya yaitu pemeriksaan kondisi jaringan periodontal. WHO juga merekomendasikan usia untuk pemeriksaan kesehatan rongga mulut, yaitu usia 12 sampai dengan 18 tahun. Usia tersebut direkomendasikan sebagai usia untuk pemeriksaan karena gigi tetap yang menjadi gigi indeks CPITN telah bertumbuh seutuhnya (Riskesdas, 2013). Tujuan dari penelitian ini adalah untuk mengetahui gambaran perilaku pemeliharaan kesehatan gigi dan mulut dengan kondisi jaringan periodontal pada Siswa SMA Negeri 1 Salem Kecamatan Salem Kabupaten Brebes

\section{METODE}

Jenis penelitian ini adalah penelitian observasional dengan rancangan penelitian menggunakan metode deskriptif yaitu untuk melihat gambaran perilaku pemeliharaan kesehatan gigi dan mulut serta kondisi jaringan periodontal pada Siswa SMA Negeri 1 Salem Kecamatan Salem Kabupaten Brebes (Budiarto, 2003). Populasi pada penelitian ini adalah Siswa Kelas XI IPS 1 SMA Negeri 1 Salem Kecamatan Salem Kabupaten Brebes yang berjumlah 36 orang, semua populasi dijadikan sampel karena kurang dari 100 (total sampling). Data yang digunakan dalam penelitian ini adalah data primer dan data sekunder. Data primer adalah data yang diperoleh dari subyek penelitian yaitu kuesioner perilaku tentang pemeliharaan kesehatan gigi dan mulut, serta penyakit jaringan periodontal dan kebutuhan perawatan pada Siswa Kelas XI IPS 1 dengan pemeriksaan Community Periodontal Index of Treatment Needs (CPITN) dan data sekunder berupa data siswa SMA kelas XI IPS 1 yang diperoleh dari SMA Negeri 1 Salem Kecamatan Salem Kabupaten Brebes. Analisa data dalam penelitian ini dituangkan dalam bentuk distribusi frekuensi

\section{HASIL DAN PEMBAHASAN}

Setelah penelitian dilaksanakan dengan memberikan kuesioner perilaku tentang pemeliharaan kesehatan gigi dan mulut sebanyak 12 item pertanyaan. Hasil dari kuesioner perilaku tentang pemeliharaan kesehatan gigi dan mulut dapat dilihat pada tabel berikut.

Tabel 1. Distribusi Frekuensi Sampel Penelitian Berdasarkan Perilaku tentang Pemeliharaan Kesehatan Gigi dan Mulut

\begin{tabular}{clcc}
\hline No. & Perilaku Responden & Jumlah $(\mathbf{n})$ & Persentase \\
\hline 1. & Kriteria Baik & 0 & 0 \\
\hline 2. & Kriteria Sedang & 36 & 100 \\
\hline 3. & Kriteria Kurang & 0 & 0 \\
\hline & Jumlah & $\mathbf{3 6}$ & $\mathbf{1 0 0}$ \\
\hline
\end{tabular}


Berdasarkan tabel 1 di atas, dapat dilihat hasil kuesioner perilaku tentang pemeliharaan kesehatan gigi dan mulut pada siswa kelas XI IPS 1 SMAN 1 Salem yaitu perilaku pemeliharaan kesehatan gigi dan mulut kriteria baik 0 orang $(0 \%)$, perilaku pemeliharaan kesehatan gigi dan mulut dengan kriteria sedang yaitu sebanyak 36 orang (100\%) dan perilaku pemeliharaan kesehatan gigi dan mulut dengan kriteria kurang 0 orang $(0 \%)$. Kemudian hasil pemeriksaan kondisi jaringan periodontal

\section{Tabel 2. Distribusi Frekuensi Sampel Penelitian Berdasarkan Pemeriksaan Kondisi Jaringan Periodontal (CPITN)}

\begin{tabular}{cclcc}
\hline No. & Skor & Kondisi Jaringan Periodontal & Jumlah (n) & Persentase (\%) \\
\hline 1. & 0 & Sehat & 0 & 0 \\
\hline 2. & 1 & Perdarahan pada gusi & 1 & 2,78 \\
\hline 3. & 2 & Ada karang gigi subgingival & 31 & 86,11 \\
\hline 4. & 3 & poket dangkal $(3,5-5,5 \mathrm{~mm})$ & 4 & 11,11 \\
\hline 5. & 4 & poket dalam (lebih dari $5,5 \mathrm{~mm})$ & 0 & 0 \\
\hline \multicolumn{7}{c}{ Jumlah } & $\mathbf{3 6}$ & $\mathbf{1 0 0}$ \\
\hline
\end{tabular}

Berdasarkan tabel 2 di atas, diperoleh hasil pemeriksaan kondisi jaringan periodontal yaitu kondisi periodontal yang sehat $(0 \%)$, ditemukan adanya perdarahan pada gusi 1 orang $(2,78 \%)$, karang gigi subgingival sebanyak 31 orang $(86,11 \%)$, poket dangkal sebanyak 4 orang $(11,11 \%)$ dan poket dalam $(0 \%)$. Hasil penelitian perilaku pemeliharaan kesehatan gigi dan mulut dengan kondisi jaringan periodontal pada siswa kelas XI IPS 1 SMAN 1 Salem terbukti memberikan gambaran. Berdasarkan penelitian dengan penyebaran kuesioner dihasilkan tidak ditemukannya perilaku baik tentang pemeliharaan kesehatan gigi dan mulut yaitu 0 orang $(0 \%)$ dan perilaku kurang 0 orang $(0 \%)$. Perilaku pemeliharaan kesehatan gigi dan mulut didominasi oleh perilaku sedang yaitu 36 orang (100\%). Perilaku tersebut banyak kemungkinan diakibatkan kurangnya pengetahuan tentang pemeliharaan kesehatan gigi dan mulut. Perilaku pemeliharaan kesehatan gigi dan mulut pada siswa kelas XI IPS 1 SMAN 1 Salem masih kurang. Hal ini dibuktikan dengan hasil pemeriksaan kondisi jaringan periodontal menggunakan CPITN tidak ditemukannya jaringan periodontal sehat yaitu 0 orang $(0 \%)$ meskipun jaringan periodontal dengan pocket dalam juga tidak ditemukan 0 orang $(0 \%)$. Sama halnya dengan hasil kuesioner yang didominasi oleh nilai sedang, kondisi jaringan periodontal yang ditemukan yaitu adanya perdarahan pada gusi 1 orang $(2,78 \%)$, adanya subgingival calculus 31 orang $(86,11 \%)$, dan pocket dangkal 4 orang $(11,11 \%)$. Hal ini menunjukkan hasil penelitian masih jauh dari target yang ditetapkan oleh WHO pada tahun 2010. WHO menerangkan $100 \%$ dari semua orang berusia 15 tahun yang termasuk important age group memiliki jaringan periodontal yang sehat, yaitu terdapat 5-6 sektan pemeriksaan CPITN yang sehat (cit. Slat, M.E., dkk, 2013). Masih jauhnya kondisi jaringan periodontal dari target tersebut disebabkan oleh rendahnya kebersihan gigi dan mulut.

Rendahnya kebersihan gigi dan mulut disebabkan oleh faktor kesadaran dan perilaku pemeliharaan kesehatan gigi dan mulut yang kurang, seperti yang dikatan oleh Notoatmodjo (2012), bahwa perilaku merupakan faktor terbesar kedua setelah faktor lingkungan yang mempengaruhi kesehatan individu, kelompok atau masyarakat. Berdasarkan kuesioner perilaku pemeliharaan kesehatan gigi dan mulut kepada siswa kelas XI IPS 1 SMAN 1 Salem didapatkan hasil penelitian yaitu seluruh siswa menggambarkan perilaku pemeliharaan kesehatan gigi dan mulut dengan kriteria sedang. hal ini dapat dilihat dari 58,3\% siswa yang menyatakan kadang-kadang menyikat gigi secara tepat waktu. Selain itu, diperoleh hasil bahwa siswa kelas XI IPS 1 SMAN 1 Salem tidak 
ditemukan perilaku pemeliharaan kesehatan gigi dan mulut dengan kriteria baik 0 orang $(0 \%)$ begitu juga dengan kriteria kurang 0 orang $(0 \%)$. Hal ini bisa dikarenakan banyak faktor, seperti yang dikatakan oleh Lawrence Green (1980), bahwa perilaku dipengaruhi oleh tiga faktor utama yaitu faktor predisposisi (predisposing factor), faktor pemungkin (enabling factor) dan faktor pendorong atau penguat (reinforcing factor). Tidak ditemukannya siswa yang memiliki perilaku pemeliharaan kesehatan gigi dan mulut dengan kriteria baik disebabkan oleh kurangnya pengetahuan tentang pemeliharaan kesehatan gigi dan mulut. Hal tersebut dapat disebabkan kurangnya informasi tentang pemeliharaan kesehatan gigi dan mulut kepada siswa kelas XI IPS 1 SMAN 1 Salem. Hal ini terlihat dari perilaku siswa yaitu $25,03 \%$ suka menyikat gigi tepat waktu, 58,3\% menyatakan kadang-kadang dan $16,67 \%$ menyatakan tidak menyikat gigi tepat waktu. Untuk menanggulangi dan merubah perilaku tersebut perlu diberikan alih pengetahuan tentang pemeliharaan kesehatan gigi dan mulut melalui pendidikan kesehatan gigi baik secara formal maupun nonformal. Pendidikan kesehatan gigi secara formal bisa dilakukan melalui penyuluhan tentang pemeliharaan kesehatan gigi dan mulut dan secara nonformal bisa melalui media massa maupun elektronik. Menurut Depkes. R.I (1996), pemeliharaan kesehatan gigi dan mulut dapat dilakukan dengan cara; menyikat gigi dengan cara yang tepat dan teratur yaitu pagi hari sesudah makan dan malam hari sebelum tidur, serta menggunakan pasta gigi yang mengandung fluor, memperhatikan diet makanan, berobat ke klinik gigi, Puskesmas/Dokter gigi bila ditemukan kelainan/penyakit gigi serta pemeriksaan kesehatan gigi dan mulut secara berkala 6 bulan sekali ke Puskesmas/Dokter gigi. Selain itu, untuk pencegahan dan perawatan penyakit periodontal yang ditemukan pada siswa kelas XI IPS 1 SMAN 1 Salem dapat dilakukan perawatan yaitu: 1) Siswa dengan kondisi jaringan periodontal adanya perdarahan pada gusi dapat diberikan Edukasi Intruksi Kesehatan Gigi dan Mulut (EIKM); 2) Siswa dengan kondisi jaringan periodontal adanya subgingival calculus dan pocket dangkal dapat dilakukan pembersihan karang gigi (scalling) serta pemberian Edukasi Intruksi Kesehatan Gigi dan Mulut (EIKM) (Putri, dkk., 2010).

\section{KESIMPULAN}

Berdasarkan hasil penelitian tentang "Perilaku Pemeliharaan Kesehatan Gigi dan Mulut dengan Kondisi Jaringan Periodontal pada Siswa SMAN 1 Salem Kecamatan Salem Kabupaten Brebes", dapat disimpulkan sebagai berikut: 1) Rata-rata kondisi jaringan periodontal siswa kelas XI IPS 1 SMAN 1 Salem berdasarkan hasil pemeriksaan Community Periodontal Index of Treatment Needs (CPITN) yaitu adanya subgingival calculus; 2) Rata-rata siswa kelas XI IPS 1 SMAN 1 Salem memiliki perilaku pemeliharaan kesehatan gigi dan mulut dengan kriteria sedang

\section{DAFTAR PUSTAKA}

Anas, N. P., 2014, Pengaruh Tingkat Pengetahuan Dan Perilaku Ibu Hamil Terhadap Terjadinya Periodontitis Di Wilayah Kerja Puskesmas Balocci Kabupaten Pangkep, Skripsi: Fakultas Kedokteran Gigi Universitas Hasanuddin Makassar.

Budiarto, E., 2003, Metodologi Penelitian Kedokteran: Sebuah Pengantar, EGC: Jakarta.

Cahyati, D., 2009, Gambaran Community Periodontal Index of Treatment Needs (CPITN) pada Usia Lanjut di Panti Jompo Welas Asih Singaparna Kabupaten Tasikmalaya, Karya Tulis Ilmiah: Jurusan Keperawatan Gigi Poltekkes Tasikmalaya. 
Depkes R.I., 1996, Petunjuk Pemeliharaan Kesehatan Gigi dan Mulut Seri Ibu Hamil dan Balita, Direktorat Jenderal Pelayanan Medik: Jakarta.

Dewanti, 2012, Hubungan Pengetahuan Tentang Kesehatan Gigi dengan Perilaku Perawatan Gigi Pada Anak Usia Sekolah Di SDN Pondok Cina 4 Depok, Skripsi: Fakultas Ilmu Keperawatan Universitas Indonesia.

Erah, 2009, Hubungan Perilaku Nelayan Terhadap Status Kebersihan Gigi dan Mulut pada Nelayan di Pantai Batukaras Desa Batukaras Kec.Cijulang Kabupaten Ciamis, Karya Tulis Ilmiah: Jurusan Keperawatan Gigi Poltekkes Tasikmalaya.

Fitriani, S., 2011, Promosi Kesehatan, Graha Ilmu: Yogyakarta.

Herijulianti, E., dkk., 2001, Pendidikan Kesehatan Gigi, EGC: Jakarta.

Houwink, B., dkk., 1993, Ilmu Kedokteran Gigi Pencegahan, Gadjah Mada University Press: Yogyakarta.

Kemenkes R.I., 2012, Undang-Undang Republik Indonesia Nomor 36 Tahun 2009 tentang Kesehatan, Badan Pengembangan dan Pemberdayaan SDM Kesehatan: Jakarta.

Kristiani, A., dkk., 2008, Ilmu Penyakit Gigi Dan Mulut, Forum Komunikasi JKG Poltekkes se-Indonesia: Tasikmalaya.

Nio, B.K., 1987, Preventive Dentistry, Yayasan Kesehatan Gigi Indonesia: Bandung.

NN., 2015, Sekolah Menengah Atas, [Online], tersedia: http://id.wikipedia.org/wiki/Sekolah_menengah_atas, [30 Januari 2015].

Notoatmodjo, S., 2010, Ilmu Perilaku Kesehatan, Rineka Cipta: Jakarta.

2012, Promosi Kesehatan dan Perilaku Kesehatan, Rineka Cipta: Jakarta.

Putri, M. H., dkk., 2010, Ilmu Pencegahan Penyakit Jaringan Keras dan Jaringan Penyangga Gigi, EGC: Jakarta.

Rahmadhan, A.G., 2010, Serba-Serbi Kesehatan Gigi dan Mulut, Bukune: Jakarta.

Riskesdas, 2013, Riset Kesehatan Dasar, Badan Penelitian dan Pengembangan Kesehatan, Kementerian Kesehatan Republik Indonesia: Jakarta.

Rohaeti, E., 2009, Hubungan Pengetahuan Kesehatan Gigi dan Mulut dengan CPITN pada Pasien Usia Dewasa yang Berkunjung ke Poliklinik RSUD Ujung Berung Kota Bandung, Karya Tulis Ilmiah: Jurusan Keperawatan Gigi Poltekkes Tasikmalaya.

Sarwono, S.W., 2013, Psikologi Remaja, Rajawali Pers: Jakarta.

Sriyono, N.W., 2005, Pengantar Ilmu Kedokteran Gigi Pencegahan, Medika-Fakultas Kedokteran UGM: Yogyakarta.

Suling, P.L., dkk., 2014, Gambaran Status Jaringan Periodontal pada Pelajar di SMA Negeri 1 Manado, Skripsi: Fakultas Kedokteran Universitas Sam Ratulangi, Manado. 